\title{
Genetic transfer of resistance to powdery mildew and of an associated biochemical marker from Aegilops ventricosa to hexaploid wheat
}

\author{
A. Delibes, I. Lopez-Braña, M. Mena and F. García-Olmedo \\ Departamento de Bioquimica, E.T.S. Ingenieros Agrónomos-UPM, E-28040 Madrid, Spain
}

\begin{abstract}
Summary. Resistance to powdery mildew, caused by the fungus Erysiphe graminis f.sp. tritici, has been transferred from Aegilops ventricosa (genomes $\mathrm{D}^{v} \mathrm{M}^{v}$ ) to hexaploid wheat (Triticum aestivum, ABD). In two transfer lines, H-93-8 and H-93-35, the resistance gene was linked to a gene encoding protein U-1, whereas one line, H-93-33, was resistant but lacked the molecular marker, and another line, H-93-1, was susceptible but carried the gene for $\mathrm{U}-1$, indicating that the original $\mathrm{M}^{\mathrm{v}}$ chromosome from Ae. ventricosa, carrying the two genes, had undergone recombination with a wheat chromosome in the last two lines.
\end{abstract}

Key words: Wheat - Aegilops ventricosa - Erysiphe graminis f.sp. tritici - Powdery mildew resistance Protein U-1

\section{Introduction}

The use in wheat breeding of genetic resistance to powdery mildew, caused by the fungus Erysiphe graminis f.sp. tritici, has been recently reviewed by Bennett (1984). Despite extensive screening of wheat cultivars, relatively few widely-effective and utilizable sources of resistance have been discovered within the species. Thus the search for alien sources of resistance to this disease is of considerable practical interest. Although resistance has been found in species of Aegilops, Triticum, Agropyron, and others, only in a few cases have the resistance genes been transferred to hexaploid wheat (Bennett 1984). Aegilops ventricosa is a source of resistance that is entirely different from any other used so far in wheat and as such could be valuable for breeding purposes. In the course of biochemical and cytological studies of hexaploid lines carrying genetic material from Ae. ventricosa, three lines that were resistant to powdery mildew were identified (Delibes and Garcia-Olmedo 1973; Delibes et al. 1977; GarciaOlmedo et al. 1984). We report here an investigation of the resistance gene transferred into these lines and of its linkage to that encoding protein U-1.

\section{Materials and methods}

The hexaploid H-93 lines, derived from the cross (Triticum turgidum $\mathrm{H}-1-\mathrm{I} \times$ A e. ventricosa AP-1) $\times T$, aestivum cv. 'Almatense $\mathrm{H}-10-15$ ', have been previously described (Delibes and García-Olmedo 1973; Delibes el al. 1977; Garcia-Olmedo et al. 1984). The inoculum of Erysiphe graminis f.sp. tritici was that predominating in the Madrid area (1984-1985) and the resistance tests were carried out in the greenhouse. A 0-9 scale for appraising foliar intensity of wheat diseases was used, following instructions issued at CIMMYT. Protein U-1 was analysed by starch-gel electrophoresis (SGE) at $\mathrm{pH} 3.2$ as previously described (Delibes and Garcia-Olmedo 1973). Mejosis was studied in Orcein-Feulgen stained squashes of pollen mother cells from anthers fixed in acetic-alcohol.

\section{Results and discussion}

A wide range of stable morphological types were obtained by repeated selfing of the progeny from a cross (Triticum turgidum $\mathrm{H}-1-1 \times$ A e, ventricosa AP-1) $\times$ T. aestivum $\mathrm{cv}$. 'Almatense $\mathrm{H}-10-15$ '. These lines designated H-93-1 to H-93-70, were found to be hexaploid and to carry genes from the $\mathrm{D}^{\mathrm{v}}$ and the $\mathrm{M}^{\mathrm{v}}$ genomes of Ae. ventricosa, which had been incorporated both by chromosomal substitution and by recombination (Delibes et al. 1977). Due to the partial homology of the $D^{4}$ genome of the donor species and the $\mathrm{D}$ genome of the recipient, genes associated with the $D^{v}$ genome ap- 


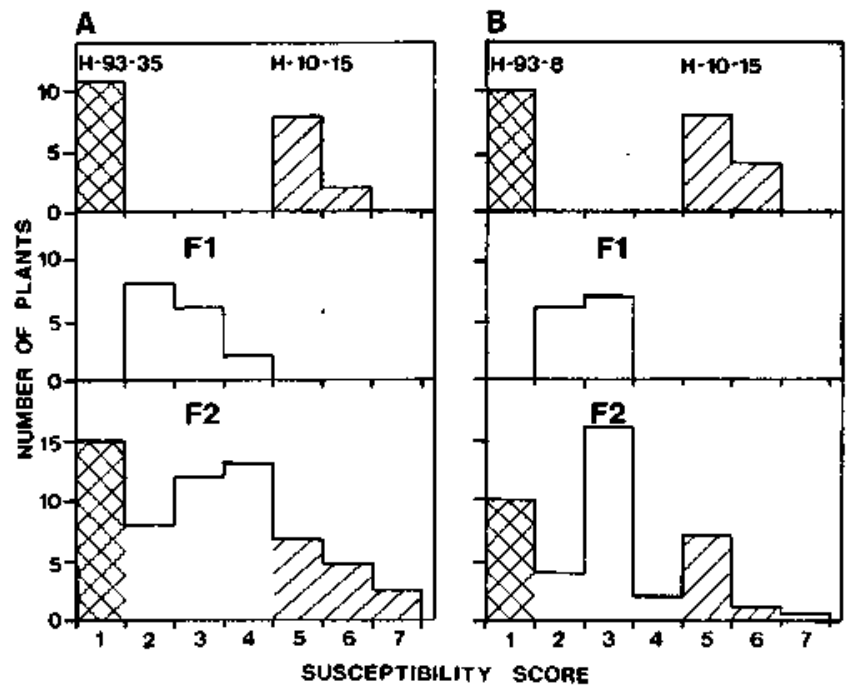

Fig. 1 A, B. Inheritance of resistance to powdery mildew in crosses between $\mathrm{H}-93$ transfer lines and $T$. aestivum cv. 'Almatense H-10-15'. No significant maternal effects were found, so the data from reciprocal crosses have been pooled. In F2 generations, plants were classified into resistant, intermediate, or susceptible, based on the susceptibility score distribution of the parents. The observed segregation in each of the F2 generations did not differ significantly $\left(\chi^{2} \leqslant \chi^{2} \quad d f=2, p=0.05=5.99\right)$ from the segregation 1 resistant $/ 2$ intermediate/ 1 susceptible expected of a single co-dominant factor. A H-93-35; B H-93-8 peared in these lines at high frequencies $(30-60 \%)$, whereas genes from the $\mathbf{M}^{v}$ genome, which is not homologous to any of the genomes of hexaploid wheat (A, B or D), generally appeared at lower frequencies $(<4 \%)$. Resistance to powdery mildew appeared in 3 out of the $70 \mathrm{H}-93$ lines (H-93-8. -33, -35), a transfer frequency which was typical of genes located in the $\mathbf{M}^{\mathbf{v}}$ genome. These lines, which had been shown to be resistant to isolates of E. graminis f.sp. Iritici from France (Delibes et al. 1977), were also resistant to isolates from Madrid (Spain). To ascertain that resistance was inherited as a single factor, lines $\mathbf{H}-93-8$ and H-93-35 were crossed with $T$. aestivum cv. 'Almatense $\mathrm{H}-10-15$, and their $\mathrm{F1}$ and $\mathrm{F} 2$ generations were scored for susceptibility to the fungus (Fig. 1).

The gene encoding protein $\mathrm{U}-1$ was tentatively assigned to the $\mathbf{M}^{\mathbf{v}}$ genome, based on its presence in $A e$. ventricosa $\left(\mathrm{D}^{v} \mathrm{M}^{\vee}\right)$, Ae comosa $(\mathrm{M})$ and Ae. uniaristata $\mathrm{M}^{\mathrm{u}}$ ), and its absence from Triticum turgidum (AB), $T$. aestivum (ABD) and Ae. squarrosa (D) (Fig. 2) and indeed it was found in the $\mathrm{H}-93$ lines at the expected low frequency, being present in only 3 of the lines $(\mathrm{H}-93-1,-8,-35)$. The fact that two of these lines were among the three that were resistant to powdery mildew suggested linkage between the gene encoding U-1 and

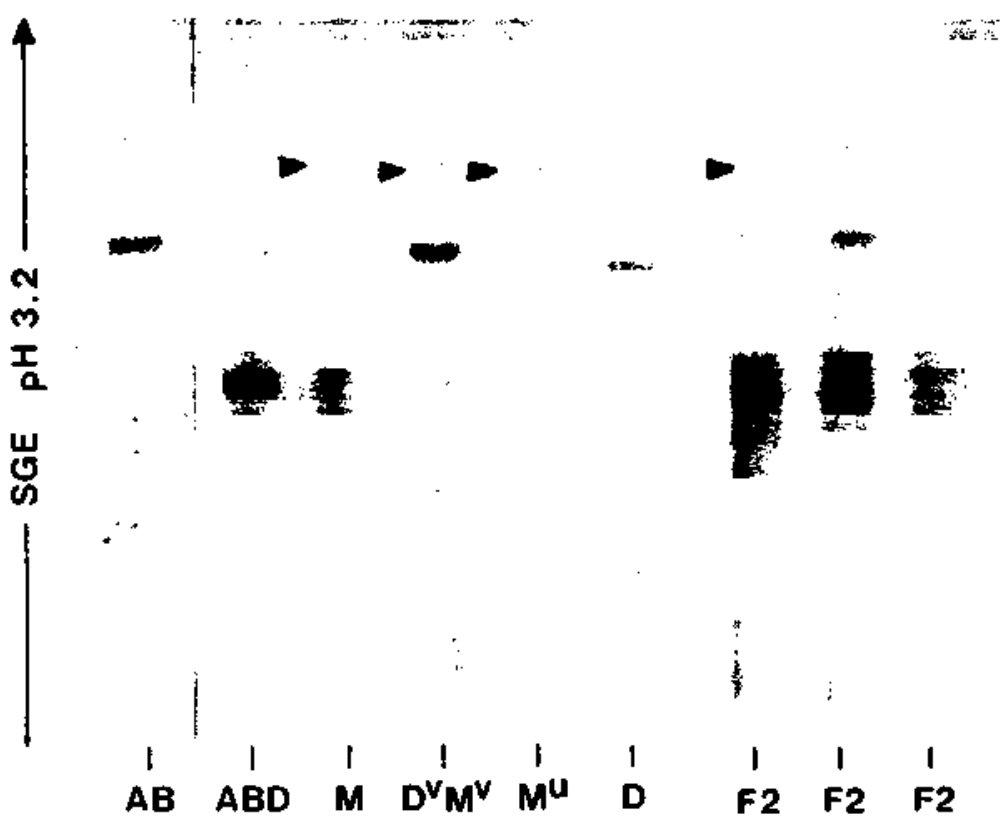

Fig. 2. Analysis of protein U-1 by starch-gel electrophoresis at $\mathrm{pH}$ 3.2: $T$. Iurgidum (AB); $T$ aestivum (ABD); Ae. comosa (M); Ae. ventricosa $\left(\mathrm{D}^{\mathrm{v}} \mathrm{M}^{\mathrm{v}}\right) ;$ Ae. uniaristata $\left(\mathrm{M}^{\mathrm{u}}\right) ;$ A e. squarrosa (D); individual kernels of the $F 2$ generations (F2). Position of protein $\mathrm{U}-1$ is indicated by an arrow $(-)$

Table 1. Genotypes and number of univalents in meiosis of $\mathrm{H}-93$ lines and their hybrids with cv. 'Almatense $\mathrm{H}-10-15$ '

\begin{tabular}{|c|c|c|c|c|c|}
\hline & \multicolumn{4}{|l|}{ Lines $\mathbf{H}-93$} & \multirow[t]{2}{*}{$\mathrm{H}-10-15$} \\
\hline & 1 & 8 & 33 & 35 & \\
\hline Resistance to powdery mildew & pmpm & $P m P m$ & $P m P m$ & $P m P m$ & pmpm \\
\hline Protein U-1 & UIUI & UIUI & & $U I U I$ & \\
\hline No, of univalents in lines & $0.28 \pm 0.10$ & $0.25 \pm 0.10$ & $1.00 \pm 0.18$ & 0.00 & $0.04 \pm 0.04$ \\
\hline No. of univalents in hybrids & $2.92 \pm 0.27$ & $4.32 \pm 0.19$ & $3.74 \pm 0.21$ & $2.56 \pm 0.22$ & \\
\hline
\end{tabular}



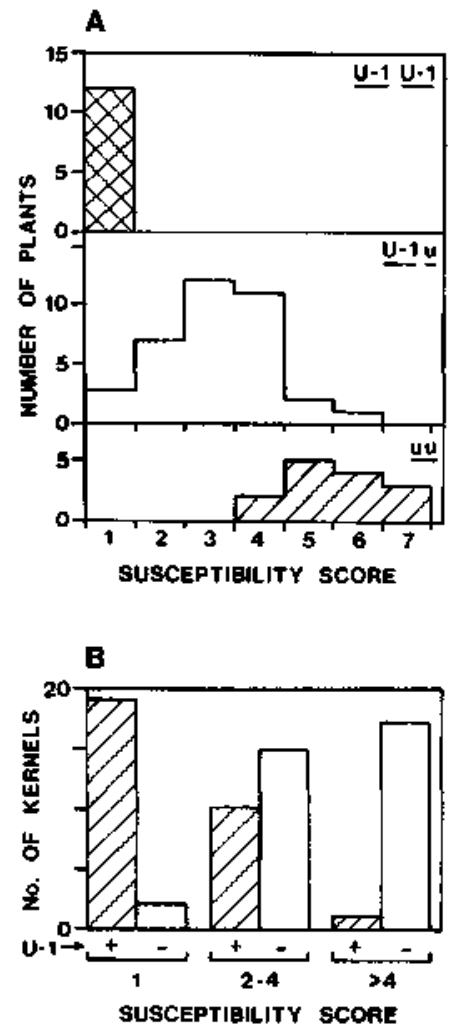

Fig. 3. A Distributions of susceptibility scores in plants from the F2 (H-93-35 $\times \mathrm{H}-10-15)$ with 2, 1 , or 0 doses of the gene encoding protein $\mathrm{U}-1$. The genotpyes were established by electrophoretic analysis of 10 kernels from each F2 plant. B Plants from the $\mathrm{F} 2$ (H-93-8 $\times \mathrm{H}-10-15)$ were grouped into three categories according to their susceptibility scores, the grain from each group was pooled and random samples were taken. Protein U-1 was analysed in each kernel from the different samples

the resistance gene. Evidence for this linkage is presented in Fig. 3. Plants from the F2 of the reciprocal crosses between line $\mathrm{H}-93-35$ and $T$. aestivtum cv. 'Almatense $\mathrm{H}-10-15$ ' were classified into homozygous, hemizygous, or null for the gene encoding $\mathrm{U}-1$ by the electrophoretic analysis of 10 individual kernels from each plant (Fig. 2). The distributions of susceptibility scores for the three classes of plants, which are represented in Fig. $3 \mathrm{~A}$, clearly indicate linkage between the gene for $U-1$ and that for resistance. A simpler approach was followed in the analysis of the $F 2$ of the cross involving H-93-8: kernels from all F2 plants with a given susceptibility score were pooled, the pools were sampled, and the presence of protein U-1 was investigated in the individual kernels from each sample. The results, which are presented in Fig. $3 \mathrm{~B}$, again confirm the linkage between the two genes.

In Table 1, the mean number of univalents in meiosis of the $\mathrm{H}-93$ lines under study and of their hybrids with $T$, aestivum cv. 'Almatense $\mathrm{H}-10-15$ ' are recorded together with the genotypes of the lines. Although the number of univalents in the hybrids indicate that the four lines probably carry whole chromosome substitutions, it can be concluded that recombination between the $\mathrm{M}^{\mathrm{v}}$ chromosome carrying the two genes and a wheat chromosome must have occurred in line H-93-1, which carries the $U-1$ gene but is susceptible to powdery mildew, and in line H-93-33, which is resistant but lacks the molecular marker. This is in agreement with our previous conclusion about recombination between chromosomes of the $\mathrm{M}^{\mathrm{v}}$ and $\mathrm{D}^{\mathrm{v}}$ genomes in the $A B D^{v} M^{v}$ hybrid formed between the donor, Ae ventricosa, and T. turgidum, the bridge species used in the transfer (Delibes et al. 1977, 1981), as well as with the recent observation by Cuñado et al. (1986) of significant $D^{v} / M^{v}$ pairing in a $R D^{v} M^{v}$ hybrid between rye and $A$ e ventricosa, while no pairing occurred in the corresponding alloploid $\left(\operatorname{RRD}^{\mathrm{v}} \mathrm{D}^{\mathrm{v}} \mathbf{M}^{\mathrm{v}} \mathbf{M}^{\mathrm{v}}\right)$.

Using different genetic material, a number of wheatAegilops ventricosa addition lines have been obtained by Dosba and co-workers which carry $\mathbf{M}^{\mathbf{v}}$ chromosomes (Dosba et al. 1978; Dosba 1985). One such line, desiganted B or 7 , was found to carry the gene for protein U-1 by Delibes et al. (1981), whereas the resistance to powdery mildew was associated with the line designated A or 5 (Dosba et al. 1978). The added chromosomes in lines A and B seem to, respectively, belong to homoeology groups 6 and 5 (see Dosba 1985). The difference in the linkage situation of the two genes in this case versus that of the H-93 lines could be adscribed to different situations in the original accessions of $A$. ventricosa used in each case or, alternatively, to chromosomal rearrangements that could have occurred during the genetic manipulations leading to the $\mathrm{H}-93$ or to the addition lines. In this context, it might be of interest that resistance to the nematode Heterodera avenoe has been associated with the same two addition lines, $A$ and B (Dosba et al. 1978; Rivoal et al. 1986).

Acknowledgement. We acknowledge grant No. 2046/83 from the Comisión Asesora de Investigación Cientifica y Técnica.

\section{References}

Bennett FGA (1984) Resistance to powdery mildew in wheat; a review of its use in agriculture and breeding programmes. Plant Pathol 33:279-300

Cuñado $\mathrm{N}$, Cermeño MC, Orellana J (1986) Interactions between wheat, rye and Aegilops ventricosa chromosomes on homologous and homoeologous pairing. Heredity 56: 219-226

Delibes A, Garcia-Olmedo F (1973) Biochemical evidence of gene transfer from the $\mathrm{M}^{\mathrm{v}}$ genome of Aegilops ventricasa to hexaploid wheat. In: Sears ER, Sears LMS (eds) Proc 4th Int Wheat Genet Symp. Mo Agric Exp Stn. Columbia Mo, pp 161-166

Delibes A, Sanchez-Monge R, Garcia-Olmedo F (1977) Biochemical and cytological studies of genetic transfer from the $\mathrm{M}^{v}$ genome of Aegilops ventricosa into hexaploid wheat. In: Sanchez-Monge E, Garcia-Olmedo (eds) Interspecific hybridization in plant breeding. Proc 8th Congr EUCARPIA. University Politéenica, Madrid, pp 81-89 
Delibes A, Otero C, Garcia-Olmedo F (1981) Biochemical markers associated with two $\mathrm{M}^{\mathrm{v}}$ chromosomes from $\mathrm{Aegi}$ lops ventricosa in wheat-Aegilops addition lines. Theor Appl Genet 60:5-10

Dosba F (1985) Méthodologie du transfert des génes d'Aegilops ventricosa a Triticum aestivum: analyse cytogénétique d'hybrides interspecifiques et étude de lignées d'addition blé-aegilops. These d'Etat, Universite de Paris-Sud. France

Dosba F, Doussinault G, Rivoal R (1978) Extraction identification and utilization of the addition lines $T$. aestivum-
Ae. ventricosa. In: Ramamujan S (ed) Proc Sth Int Wheat Genet Symp. Indian Agr Res Inst, New Delhi, pp 332-337

Garcia-Olmedo F, Delibes A, Sanchez-Monge R (1984) Transfer of resistance to eyespot disease from Aegilops ventricosa to wheat. Vortr Pflanzenzilicht 6: 156-168

Rivoal R, Dosba F, Jahier J, Pierre JS (1986) Les lignés d'addition blé-Aegilops ventricosa Tausch IV. Etude de la localisation chromosomique de la résistance á l'égard d'Heterodera avenae Woll. Agronomie 6:143-148 